\title{
A genetic study of a Staphylococus aureus plasmid involving cure and transference
}

\author{
Discipline of Clinical Bacteriology \\ Department of Clinical, Toxicological and Bromatological Analysis \\ College of Pharmaceutical Sciences - University of São Paulo
}

High frequency transfer and elimination of drug resistance may indicate an extrachromosomal inheritance of genetic determinants. This study shows the cure and transfer of a small plasmid and tetracycline resistance in Staphylococcus aureus 1030 (55) Tet $^{A}$ strains. Several methods are available for plasmid elimination. We used ethidium bromide, an agent that binds to DNA, and thus inhibits DNA polymerase. This caused a high frequency of loss of the small plasmid and resistance to tetracycline. Transfer of tetracycline resistance was done in a mixed culture at a frequency of $10^{-6}$. This type of study is very important to physicians and epidemiology investigators and provides better knowledge on antibiotic-resistance mechanisms that may occur in vivo in a hospital environment.

UNITERMS: S. aureus. Cure. Conjugation. Plasmids. Transference.

\section{INTRODUCTION}

$\mathrm{S}$ everal criteria are available to determine, in bacteria, whether there are genes for resistance to antibacterial drugs in plasmids or in chromosomes. One criterium is the transfer of plasmids between bacteria, while another is the instability of one or more bacterial phenotypes, which would mean that some genes are located on plasmids ${ }^{1.7 .8}$.

In transfer experiments, it has been noted that resistance determinants encoded in plasmids may be

\section{Address for correspondence:}

Ana Lúcia Costa Darini

Departamento de Análises Clínicas, Toxicológicas e

Bromatórias - Disciplina de Bacteriologia Clínica

Faculdade de Ciências Farmacêuticas - USP

Ribeirão Preto/SP - Brasil - CEP 14040-903 transferred in mixed cultures at high frequencies after an 18-hour incubation period. Genes for resistance in chromosomes may also be transferred, although at smaller frequencies ${ }^{6,7}$.

In 1980, LACEY proposed an alternate, more efficient mechanism of genetic transfer, referred to as phage mediated conjugation because of the necessity of a prophage in the donor as well as the recipient strains, and requiring $\mathrm{Ca}^{++}$and an increase in bacterial population density ${ }^{5}$. This mechanism differs from transduction since the donor does not need to be lysogenic, and the transfer is not made from a phage donor after lysis. Little spontaneous phage activity is found in culture media, and the filtrates do not necessarily contain any transductive particles. The nature of this non-transduction mechanism is supported by the discovery that the transfer occurred between donor and recipient cells when both suffered a lysogenization by a mutant phage incapable of forming 
phagic heads. Although the exact nature of prophage involvement is unknown, LACEY stated that bacteriophages can be considered as an "instrument" in the alteration of the cell's surface, increasing cell grouping and allowing the passage of plasmid DNA directly from the donor to the recipient ${ }^{5.6}$.

In experiments with phenotype instability, there are methods which describe spontaneous or induced plasmid cure. When the culture is stored at room temperature for some months, a plasmid cell-positive population can spontaneously revert to plasmidnegative when the selective agent (i.e. antibiotic) is removed from the medium. While using incubation temperatures that are different from those that are ideal for bacterial growth, a plasmid cure may occur. The recommended temperature is generally $5-10^{\circ} \mathrm{C}$ above what is routinely used, which still permits bacterial growth. Plasmid cure may also occur while using curative agents such as ethidium bromide.

The purpose of this study is to determine the relation between the presence of plasmids in a Staphylococcus aureus strain and its resistance to tetracycline. It also demonstrates the importance of studying plasmid gene transfer mechanisms in $S$. aureus strains.

\section{MATERIAL AND METHODS}

For plasmid transfer the method employed here was conjugation mediated by phagi or "mixed culture," described by LACEY ${ }^{6}$. This study was carried out with donor and recipient strains of $S$. aureus. These strains were built by LACEY from $S$. aureus 1030, which is lysogenic and susceptible to all antibiotics. For the construction of the donor strain, plasmid genes were transduced to the wild strain $S$. aureus 1030, which then received a new denomination: S. aureus 1030 (55) Tet $\mathrm{R}^{5}$. The recipient strain, S. aureus 1030 (55) S, which is also lysogenic for Phage 55, shows chromosomal resistance to streptomycin (S).

For the development of this method, it was necessary to determine the level of resistance of the donor strain ( $S$. aureus $1030(55) \mathrm{Tet}^{\mathrm{R}}$ ) to tetracycline in order to prepare the culture media with adequate concentrations of this drug. For the recipient strain ( $S$. aureus $1030(55) \mathrm{S})$, the minimum inhibitory concentration for streptomycin was obtained by LACEY
Donor and recipient strains were incubated separately in $2 \mathrm{ml} \mathrm{LB}$ medium at $37^{\circ} \mathrm{C}$. After $18-20$ hours, $200 \mathrm{ml}$ of each culture were transferred to a $50 \mathrm{ml}$ Erlenmeyer with $2 \mathrm{ml}$ of $\mathrm{CaCl}_{2} 0.01 \mathrm{M}$ added to $20 \mathrm{ml}$ of LB medium. This culture was incubated at $37{ }^{\circ} \mathrm{C}$ under constant agitation of $100 \mathrm{rpm}$ for $18-20$ hours. After this, $100 \mathrm{ml}$ samples were placed in $1290 \mathrm{~nm}$ Petri dishes with Mueller-Hinton agar containing drugs capable of selecting transconjugants by acting on donor plasmids. A control was used during every step of the procedure.

The study for plasmid elimination was made following the Bouanchaud et al. method using $S$. aureus $1030(55) \mathrm{Tet}^{\mathrm{R}}$ strains $^{3}$. Culture incubation was conducted with ethidium bromide. The ideal concentration for this curative agent is the highest concentration possible which does not inhibit bacterial growth.

Cultures were placed in a nutrient medium with ethidium bromide in previously established concentrations of 3 and $4 \mathrm{mg}$ of ethidium bromide per milliliter of culture medium. A control culture was always included.

Incubation was at $37^{\circ} \mathrm{C}$ for 18 hours. Afterwards, the cultures were diluted $\left(10^{-5}\right.$ times for culture controls and $10^{-2}$ for the others), seeded in Mueller-Hinton agar and incubated again under the sames conditions as above.

The colonies were then transferred to other dishes with Mueller-Hinton medium containing $5 \mathrm{mg} / \mathrm{ml}$ of tetracycline per culture medium. Cure results were given in percentages.

\section{RESULTS}

Resistance levels of the studied strains to tetracycline and streptomycin are listed in Table 1.

Table 1

Resistance levels of S. aureus 1030 (55) S to tetracycline and streptomycin

\begin{tabular}{|c|c|c|c|}
\hline \multirow[t]{2}{*}{ Strains } & \multicolumn{3}{|c|}{$\operatorname{CIM}(\mu \mathrm{g} / \mathrm{ml})^{*}$} \\
\hline & Tet. & & $\mathrm{Sm}$ \\
\hline S. aureus $1030(55)$ Tet $^{\circledR}$ & 32 & & $S^{\star \star}$ \\
\hline S. aureus 1030 (55) S & 0.125 & 100 & \\
\hline
\end{tabular}

* MIC - maximum inhibitory concentration ( $\mu \mathrm{g}$ of drug per $\mathrm{ml}$ of culture medium).

** Data provided by LACEY (1980). S indicates suspectibility to streptomycin. 
According to Table 1, selective mediums used to select recipient and donor cells contained, respectively, $100 \mathrm{mg} / \mathrm{ml}$ of Sm and $20 \mathrm{mg}$ of tetracycline per milliliter of culture medium. For transconjugant cells $(S$. aureus $1030(55) \mathrm{S}-\mathrm{Tet}^{\mathrm{R}}$ ), the selective medium contained both drugs at the above-mentioned concentrations. In the controls for mutant detection, no isolated recipient or donor strain resistant to tetracycline was isolated.

The CFU (colony forming units) count of donor and recipient strains was conducted twice at three different dilutions, and was determined from the mean number of colonies at each dilution after Petri dish incubation at $37{ }^{\circ} \mathrm{C}$ for 24 hours. The total number of colonies in this experiment was $1.3 \times 10^{7}$ for donors and $3.4 \times 10^{8}$ for recipients.

There were 46 colonies of transconjugants $(S$. aureus $\left.1030(55) \mathrm{S}-\mathrm{Tet}^{\mathrm{R}}\right)$, determined by mean growth in 12 Petri dishes containing antibiotics ( $\mathrm{Sm} 100 \mathrm{mg} /$ $\mathrm{ml}$ and Tet $20 \mathrm{mg} / \mathrm{ml}$ ), after 24 hours of incubation.

According to LACEY, the frequency of plasmid transfer is calculated by:

$$
\text { Freq. of transfer }=\frac{\text { number of transconjugants }}{\text { number of donor colonies }}
$$$$
\text { Freq. of transfer }=\frac{46}{1.3 \times 10^{7}}=3.5 \times 10^{-6}
$$

Plasmid transfer from donors to recipient strains was also confirmed after determining the resistance
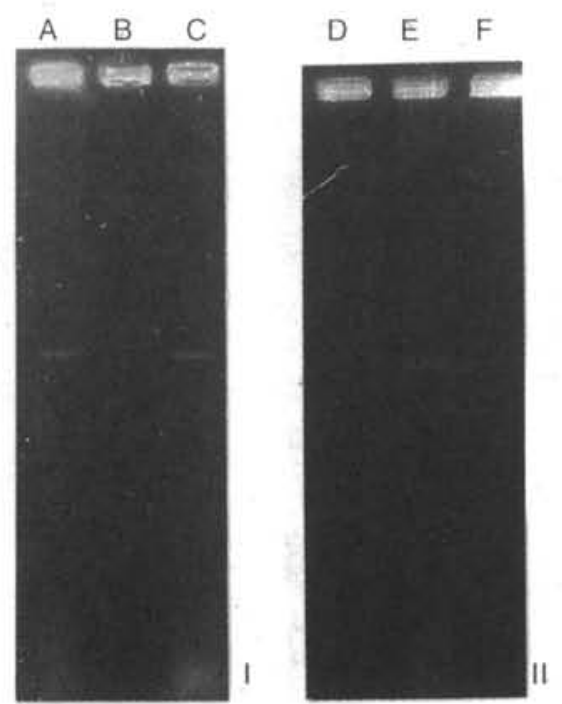

Figure 1 - Electrophorograms of plasmid DNA on S. aureus $1030(55)$ strain $0.8 \%$ agarose gel.

1- Study of plasmid transfer: A- S. aureus 1030 (55) Tet ${ }^{\mathrm{R}}$. B-

S. aureus 1030 (55) S. C- S. aureus 1030 (55) S Tet ${ }^{\text {P. }}$.

II- Study of plasmid cure: D- S. aureus 1030 (55) Tet ${ }^{\mathrm{A}}-\mathrm{C}_{9}$. E-

S. aureus 1030 (55) Tet $^{\mathrm{R}}$. F- S. aureus 1030 (55) S Tet ${ }^{\mathrm{R}}-\mathrm{C}_{12}$ level of S. aureus 1030 (55) S - Tet ${ }^{\mathrm{R}}$. For this recipient strain that received the plasmid (transconjugant), the MIC for tetracycline was $32 \mathrm{mg} / \mathrm{ml}$. After comparing these results to those shown in Table 1, the same level of resistance of the donor strain was observed after transfer.

Through plasmid extraction and analysis in agarose gel, the plasmid profiles of donor, recipient and transconjugant strains can be seen in Figure 1.

For a plasmid cure, the necessary ethidium bromide concentration in the culture medium is the highest concentration which does not inhibit bacterial growth. In this study, ethidium bromide at $4 \mathrm{mg}$ per milliliter of medium culture showed the best results.

The resistance level to tetracycline and the presence of plasmids in supposedly cured strains are

\section{Table 2}

Resistance level to tetracylcine in supposedly cured S. aureus 1030 (55) Tet $^{R}$ strains

\begin{tabular}{ccc}
\hline $\begin{array}{c}\text { S. aureus } \\
1030(55) \text { Tet }^{\mathrm{P}}\end{array}$ & $\begin{array}{c}\text { Tetracycline } \\
\text { resistance levels }\end{array}$ & $\begin{array}{c}\text { Presence of } \\
\text { plasmids }\end{array}$ \\
\hline$-C_{1}{ }^{* *}$ & 4 & $(-)$ \\
$-C_{2}$ & 4 & $(-)$ \\
$-C_{3}$ & 4 & $(-)$ \\
$-C_{4}$ & 4 & $(-)$ \\
$-C_{5}$ & 4 & $(-)$ \\
$-C_{6}$ & 4 & $(-)$ \\
$-C_{7}$ & 32 & $(+)$ \\
$-C_{8}$ & 4 & $(-)$ \\
$-C_{9}$ & 4 & $(-)$ \\
$-C_{10}$ & 32 & $(+)$ \\
$-C_{11}$ & 4 & $(-)$ \\
$-C_{12}$ & 4 & $(-)$ \\
$-C_{13}$ & 4 & $(-)$ \\
$-C_{14}$ & 4 & $(-)$ \\
$-C_{15}$ & 4 & $(-)$ \\
$-C_{16}$ & 4 & $(-)$ \\
$-C_{1}{ }^{*}$ & 32 & $(+)$ \\
$-C_{2}{ }^{*}$ & 32 & $(+)$ \\
$-C_{3}{ }^{*}$ & 32 & $(+)$ \\
$-C_{4}{ }^{*}$ & 32 & $(+)$ \\
$-C_{5}{ }^{*}$ & 32 & $(+)$ \\
$-C_{6}{ }^{*}$ & 32 & $(+)$ \\
\hline
\end{tabular}

$C^{*}$ control incubation strains

**: (-) absence of plasmid

(+) presence of plasmid 
shown in Table 2, which lists 16 strains that were supposedly cured by ethidium bromide. There were only two (S. aureus $1030(55) \mathrm{S}-\mathrm{Tet}^{\mathrm{R}} \mathrm{C}_{7}$ and $\mathrm{C}_{10}$ ) which did not lose their resistance to tetracycline and the plasmids with the genes responsible for this resistance. All six of the control strains which were supposedly cured lost neither their resistance nor their plasmids.

The loss of the plasmid of the studied strain, after treatment with the curative agent, can be noted in Figure 1(II). As a result of the analysis, the percentage of cure of the plasmid of the S. aureus 1030 (55) $\mathrm{Tet}^{\mathrm{R}}$ strain was calculated to be 3.5 percent.

\section{DISCUSSION}

Ethidium bromide binds to DNA, causing an alteration of molecular conformation which affects the synthesis of nucleic acids and leads to the elimination of plasmids. The results show the loss of the phenotypic characteristic of tetracycline resistance and of a band related to the plasmid which is responsible for this phenotype. The study on resistance elimination and plasmid cure showed that the resistance marker was lost in high frequencies.
Plasmid cure through any of the aforementioned methods greatly aids epidemiological studies on bacterial hospital infections, and is also important to the study of antibiotic resistance transfer mechanisms in a hospital environment ${ }^{2}$.

There does not seem to be an agent which can cure every plasmid in different bacteria. Therefore, in these cases, several methods should be associated. The incapacity to demonstrate the instability of a marker, whether in an induced or a spontaneous form, does not rule out plasmid inheritance in a bacterial population .

Staphylococci plasmids that participate in a DNaseresistant transfer system which requires cellular contact are usually transferred in high frequencies. This was confirmed in our experiment by a frequency of $10^{-6}$.

The standardization of these experiments is of fundamental importance for the study of conjugative plasmids, and the mechanism of conjugative transfer in vivo may be conducted in solid or liquid media cultures capable of supporting the transfer. This study has great importance for epidemiological studies of hospital infections, because it may enlighten researchers as to possible transfer mechanisms that may occur in vivo on dry (clothing, surgical material) or on humid surfaces, such as vaporizers, incubators, dialysis equipment, antiseptics, or in body fluids.

\section{Resumo}

A transferência e a eliminaçāo de resistência a drogas, em altas frequências, podem evidenciar herança extracromossômica de determinantes genéticos. Este trabalho mostra a cura e transferência de resistência à tetraciclina e de um plasmidio pequeno, na linhagem S. aureus 1030 (55) Tet ${ }^{\mathrm{A}}$. São várias as metodologias disponiveis para a eliminaçāo de plasmidios. Empregou-se a técnica do agente curagénico brometo de etidio, que se intercala na fita de DNA, inibindo o DNA polimerase. O resultado foi perda do plasmidio e da resisténcia a tetraciclina em alta frequêencia. $O$ experimento de transferència foi realizado em meio de cultura liquido, e a frequénecia foi da ordem de $10^{\circ}$. Esses estudos tèm grande importância em estudos de infecçōes. dando aos pesquisadores e clinicos esclarecimento de possiveis mecanısmos de aquisição de resistência a antibióticos que podem ocorrer também in vivo, principalmente no ambiente hospitalar. 


\section{REFERENCES}

1. Back NA, Linnemann CC, Pfaller MA, Staneck JL, Morthland, V. Recurrent epidemics caused by a single strain of eritromycin-resistent Staphylococcus aureus: The importance of molecular epidemiology. JAMA 1993;270(11):1329-33.

2. Barg NL. Environmental contamination with Staphylococcus aureus and outbreaks: the cause or the effect? Infect Control Hosp Epidemiol 1993;14:376-8.

3. Bouanchnaud DH, Scavizzi MR, Chabbert YA. Elimination by ethidium bromide of antibiotic resistance in enterobacteria and staphylococci. J Gen Microbiol 1969;54:417-25.
4. Boyce JM. Methicillin-resistance Staphylococcus aureus in hospital and long-terms care facilities: microbiology, epidemiology and preventive measures. Inf Cont Hosp Epidemio 1992;3:725-37.

5. Lacey RW. Evidence for two mechanisms of plasmid transfer in mixed cultures of Staphylococcus aureus "in vitro." J Gen Microbiol 1980;119:423-35.

6. Lacey RW. Transfer of chromosomal genes between Staphylococci in mixed cultures. J Gen Microbiol 1972;71:399-401,

7. Lyon RB, Skurray R. Antimicrobial resistance of Staphylococcus aureus: genetic basis. Microbiol Rev 1987;51(1):88-134.

8. Stanisich VA. Identification and analysis of plasmids at a genetic level. In: Grinsted J, Bennett PM, eds. Methods in microbiology, 2 ed. London:Academic Press, 1988:11-48. 